\title{
Keabsahan Akta PPAT Yang Tidak Ditandatangani Para Saksi (Studi Putusan PN. No.16/Pdt.G/2015/Pn.Krg)
}

\author{
Valerio Xaverius Tjipto \\ Magister Kenotariatan FH USU \\ E-Mail : valerio.xaverius1995@gmail.com
}

\begin{abstract}
Abstrak
Akta PPAT adalah akta autentik dalam hal. perbuatan hukum tertentu khususnya dalam hal. peralihah hak atas tanah dari satu pihak ke pihak lain. Suatu akta autentik adalah akya yang dibuat oleh pejabat yang berwenang untuk itu, di tempat dimana akta tersebut dibuat dan format nya sesuai dengan ketentuan peraturan perundangundangan yang berlaku. Akta autentik PPAT wajib dibacakan dihadapan para penghadap, dan ditandatangani oleh para penghadap saksi-saksi dan PPAT. Kedudukan hukum saksi dalam akta autentik PPAT adalah sebagai saksi instrumentair yang menyaksikan dan mengetahui pembuatan akta PPAT tersebut dan juga sebagai alat bukti yang menguatkan telah terjadi pembuatan akta PPAT tersebut. Apabila terjadi permasalahan hukum terhadap akta PPAT tersebut maka saksi instrumentair yang menandatangani akta PPAT tersebut dapat dimintai keterangannya berkaitan dengan pelaksanaan pembuatan akta PPAT tersebut, termasuk keterangan mengenai kehadiran para penghadap yang menandatangani akta PPAT tersebut dihadapan PPAT dan para saksi tersebut. Permasalahan dalam penelitian ini yaitu Bagaimana pengaturan hukum tentang saksi dalam akta PPAT, Bagaimana akibat hukum terhadap akta PPAT yang penandatanganannya dilakukan tidak dihadapan dua orang saksi dan Bagaimana analisis hukum pertimbangan Majelis Hakim dalam Putusan Pengadilan Negeri Karanganyar No. 16/Pdt.G/2015/PN.Krg.Jenis penelitian ini adalah penelitian yuridis empiris, dimana pendekatan terhadap permasalahan dilakukan dengan mengkaji pelaksanaan kewajiban PPAT berdasarkan peraturan perundang-undangan yang berlaku dalam hal. ini adalah Pasal 21 dan 22, PP No. 24 Tahun 2016 tentang perubahan atas PP No. 37 Tahun 1998 tentang peraturan jabatan PPAT dan penelitian ini juga didukung dengan melakukan wawancara secara langsung dengan 3orang PPAT yang wilayah kerjanya berada di Kota Medan.Hasil penelitian menyatakan bahwa pengaturan hukum tentang saksi dalam akta PPAT termuat di dalam Pasal 21 dan 22, PP No. 24 Tahun 2016 tentang perubahan atas PP No. 37 Tahun 1998 tentang peraturan jabatan PPAT, Pasal 18 ayat 3,4 dan 5 peraturan Menteri Negara Agraria/Kepala Badan Pertanahan Nasional (BPN) Nomor 1 Tahun 2006 Tentang Ketentuan Pelaksanaan Peraturan Pemerintah Nomor 37
\end{abstract}

\section{ReCltol}


Tahun 1998 tentang Peraturan Jabatan PPAT, Pasal 1895-1912 KUH Perdata dalam uraian mengenai kriteria saksi yang diakui dalam pembuatan akta PPAT dan Pasal 37 PP No. 24 Tahun 1997 tentang pendaftaran tanah, Akibat hukum terhadap akta PPAT yang penandatanganannya dilakukan tidak dihadapan dua orang saksi adalah bahwa akta PPAT tersebut terdegradasi menjadi akta dibawah tangan, karena mengandung cacat hukum secara formal dan Analisis hukum pertimbangan Majelis Hakim dalam Putusan Pengadilan Negeri Karanganyar No. 16/Pdt.G/2015/PN.Krg yang menyatakan bahwa PPAT telah melakukan perbuatan melawan hukum dan akta autentik tersebut telah terdegradasi menjadi akta di bawah tangan.

\title{
Kata Kunci: Keabsahan, Akta PPAT.
}

\begin{abstract}
PPAT Deed is an authentic deed in the case of certain legal actions, especially in the case of transfer of land rights from one party to another party. An authentic deed is a deed made by an authorized official for that, in the place where the deed was made and the format is in accordance with the provisions of the legislation in force. The authentic PPAT deed must be read in front of the parties, and signed by the witnesses and PPAT. The legal standing of witness in the PPAT authentic deed is as an instrument witness who witnessed and knew the making of the PPAT deed and also as evidence to strengthen the PPAT deed was made. If there is a legal problem with the PPAT deed, the instrumentair witness who signed the PPAT deed can be asked for information relating to the implementation of the PPAT deed, including information about the presence of the parties who signed the PPAT deed before the PPAT and the witnesses. The problem in this research is how the legal arrangement of witnesses in the PPAT deed, How is the legal effect on the PPAT deed whose signature was carried out in the presence of two witnesses and How is the legal analysis considered by the Panel of Judges in the Karanganyar District Court Decision No. 16 / Pdt.G / 2015 / PN.Krg.This type of research is empirical juridical research, in which the approach to the problem is carried out by reviewing the implementation of PPAT obligations based on the applicable laws and regulations in this case are Articles 21 and 22, PP No. 24 of 2016 concerning amendments to PP No. 37 of 1998 concerning PPAT position regulations and this research was also supported by conducting direct interviews with 3 PPAT people whose working area was in Medan City. The results of the study stated that the legal arrangements regarding witnesses in the
\end{abstract}

\section{ReClţ}


PPAT deed contained in Articles 21 and 22, PP No. 24 of 2016 concerning amendments to PP No. 37 of 1998 concerning PPAT position regulations, Article 18 paragraphs 3, 4 and 5 of the regulation of the State Minister for Agrarian Affairs / Head of the National Land Agency (BPN) Number 1 of 2006 concerning Provisions for Implementing Government Regulation Number 37 of 1998 concerning PPAT Position Regulations, Article 1895-1912 Civil Code in the description of the criteria for witnesses recognized in making the PPAT deed and Article 37 PP No. 24 of 1997 concerning land registration, the legal consequence of the PPAT deed which was signed before two witnesses was that the PPAT deed was degraded to a deed under the hand, because it contained a formal legal flaw and the legal analysis of the Judge Panel's consideration in the Karanganyar District Court Decision No. 16 / Pdt.G / 2015 / PN.Krg which states that the PPAT has committed acts against the law and the authentic deed has been degraded to a deed under the hand.

Keywords: PPAT Law, PPAT Deed, and the Witness Position.

\section{Pendahuluan}

Peralihan hak atas tanah melalui jual beli menurut UUPA No.5 Tahun 1960 adalah proses yang dapat menjadi bukti adanya peralihan hak dari penjual kepada pembeli. Prinsip dasarnya adalah Terang dan Tunai, yakni dilakukan di hadapan pejabat umum yang berwenang dan dibayarkan secara tunai. Ini artinya jika harga yang dibayarkan tidak lunas maka proses jual beli belum dapat dilakukan.Pejabat umum yang berwenang dalam membuat akta peralihan hak atas tanah dari pihak penjual kepada pihak pembeli dalam hal. peralihan hak atas tanah melalui jual beli adalah PPAT (Pejabat Pembuat Akta Tanah) yang diangkat dan diberhentikan oleh Kepala Badan Pertanahan Nasional RI. ${ }^{1}$

Kewenangan PPAT dalam membuat akta autentik adalah meliputi pembuatan akta-akta tertentu, seperti Akta Jual Beli, Tukar Menukar, Hibah, Pemberian Hak Bangunan atas Tanah Hak Milik, Pemberian Hak Tanggungan, Pemasukan ke dalam Perusahaan, Pembagian Hak Bersama dan Pemberian Hak Pakai atas Tanah Hak Milik. ${ }^{2}$ Sebelum melakukan proses jual beli, penjual maupun pembeli harus memastikan bahwa tanah tersebut tidak sedang dalam sengketa atau tanggungan di

${ }^{1}$ Herlin Budiono, Kumpulan Tulisan Hukum Perdata di Bidang Kenotariatan, Citra Aditya Bakti, Bandung, 2007, hal. 50.

${ }^{2}$ Saputro, Jati Diri Notaris di Indonesia, Dulu, Sekarang, dan Dimasa Mendatang. Gramedia Pustaka, Jakarta. 2009, hal. 121

\section{ReCl teview Vol. 2 No.2 Tahun 2020. E-ISSN: 2623-2928}


Bank. Jika tanah tersebut sedang dalam permasalahan maka PPAT dapat menolak pembuatan Akta Jual Beli yang diajukan. Hal. ini sesuai dengan ketentuan Pasal 2 PP No.24 Tahun 2016 tentang Peraturan Jabatan PPAT. Pasal 1 PP No.24/2016. ${ }^{3}$

PPAT hanya berwenang untuk membuat akta-akta PPAT berdasarkan penunjukannya sebagai PPAT, di sesuatu wilayah dan perbuatan-perbuatan hukum sebagaimana diatur dalam Pasal 2 ayat (2) PP No. 24 Tahun 2016 tentang perubahan atas PP No. 37 Tahun 1998 tersebut. Sedangkan kewenangan PPAT khusus tersebut adalah pembuatan akta PPAT yang secara khusus ditentukan.

Pasal 21 ayat (1) PP No. 24 Tahun 2016 disebutkan bahwa untuk memenuhi syarat autentiknya suatu akta, maka akta PPAT wajib ditentukan bentuknya oleh Menteri dalam hal. ini adalah Menteri Agraria dan Tata Ruang/Kepala BPN.Pasal 22 ayat 1 PP No. 24 Tahun 2016 bahwa akta PPAT harus dibacakan/ dijelaskan isinya kepada para pihak dengan dihadiri oleh sekurang-kurangnya 2 (dua) orang saksi sebelum ditanda tangani seketika itu juga oleh para pihak, saksi-saksi dan PPAT. Setiap lembar akta PPAT asli yang disimpan oleh PPAT harus dijilid sebulan sekali dan disetiap jilid terdiri dari lima puluh lembar akta dengan jilid terakhir setiap bulan memuat lembar-lembar akta sisanya. ${ }^{4}$

Saksi PPAT harus dikenal oleh PPAT atau diperkenalkan kepada PPAT dan kewenangannya kepada PPAT oleh penghadap.Pengenalan atau pernyataan tentang identitas dan kewenangan saksi dinyatakan secara tegas dalam akta. Saksi ialahseseorang yang dijadikan alat bukti dapat memperkuat pembuktian bahwa telah ada hubungan hukum yang terjadi dengan dibuatnya perjanjian karena perjanjian di bawah tangan tidak sekuat akta autentik. ${ }^{5}$

Saksi Atterterend atau disebut juga dengan saksi pengenal, yakni saksi yang memperkenalkan penghadap kepada PPAT dikarenakan penghadap tersebut tidak bisa dikenal PPAT atau dikarenakan tidak memiliki identitas atau PPAT meragukan identitasnya, maka PPAT minta diperkenalkan oleh saksi atterterend. Pengenalan penghadap tersebut harus dinyatakan dalam akta. ${ }^{6}$ Pada saat penandatanganan akta

${ }^{3}$ Habib Adjie, Hukum Notaris Indonesia, Tafsir Tematik terhadap Undang-Undang No. 37 Tahun 1998 tentang Notaris. Refika Aditama, Surabaya. 2007, hal. 150.

${ }^{4}$ Khairunisyah Harahap, Problematika Hukum Sebagai Camat Pejabat Pembuat Akta Tanah Sementara (PPAT/S) Dalam Melaksanakan Peralihan Hak Atas Tanah Tanpa Sertifikat.Tesis MKn. 2014.

${ }^{5} \mathrm{https}: / /$ m.hukumonline.com

${ }^{6}$ Irrenera Putri, Tinjauan Yuridis terhadap Perlindungan Karyawan PPAT sebagai Saksi dalam Pembuatan Akta, Erlangga, Surabaya, 2013, hal. 127.

\section{ReCIt_ol Vol. 2 No.2 Tahun 2020. E-ISSN: 2623-2928}


seorang saksi atterterend tidak diharuskan menandatangani, namun apabila mereka tetap ingin membubuhkan tanda tangannya tidak ada larangan untuk hal. tersebut. ${ }^{7}$

Saksi instrumen atau disebut juga saksi akta yaitu saksi dalam pembuatan akta PPAT yang membubuhkan tanda tangannya sebagai saksi di dalam akta PPAT tersebut yang memberikan kesaksian tentang kebenaran telah dipenuhinya syaratsyarat formal yang diwajibkan dalam pelaksanaan pembuatan akta autentik PPAT sesuai ketentuan Pasal 22 ayat 1 PP No. 24 Tahun 2016 dimana saksi instrument tersebut biasanya adalah karyawan PPAT tersebut. ${ }^{8}$

Saksi akta (saksi instrumentair/instrumentaire getuigen) adalah saksi yang mengetahui semua aspek formalitas pembuatan akta dilakukan dikantor/dihadapan PPAT. Seharusnya saksi akta (saksi instrumentair/instrumentaire getuigen) karyawan kantor PPAT sendiri karena sudah pasti memahami/mengetahui semua aspek formalitas pembuatan akta dilakukan dikantor/dihadapan PPAT. Jika ada para penghadap membawa saksi sendiri tidak perlu namanya dicantumkan/disebutkan pada bagian akhir akta sebagai saksi akta tapi kehadiran dan pencantuman/penyebutan namanya dapat dilakukan sebelum akhir akta saja, karena mereka berkedudukan sebagai saksi fakta untuk para pihak/penghadap. ${ }^{9}$

Berdasarkan Putusan Pengadilan No. 16/Pdt.G/2015/PN.Krg tentang sengketa keabsahan akta PPAT dimana penggugat DW mengajukan gugatan kepada WB, DS, DZAM, EB (PPAT). Kasus ini diawali dengan adanya hutang dari DW kepada Bank BPD Jateng sebesar Rp 600.000.000,- (enam ratus juta rupiah) dengan jaminan sertipikat hak miliki No. 113 dengan luas tanah $\pm 324 \mathrm{~m}^{2}$ atas nama DW terletak di Badranasri RT.02 RW.11 Kelurahan Cangakan, Kecamatan Karanganyar, Kabupaten Karanganyar, Jawa Tengah. Hutang DW tersebut diangsur rutin setiap bulan oleh DW hingga Maret 2006 dan masih tersisa total hutang DW Rp 473.275.100,- (empat ratus tujuh puluh tiga juta dua ratus tujuh puluh lima ribu seratus rupiah). WB sebagai tergugat 1 (satu) menemui DW selaku penggugat dengan maksud memberi pinjaman kepada DW sebesar sisa hutang DW di BPD Jawa Tengah tersebut. DW menyetujui pemberian pinjaman dari WB sehingga pada Tanggal 3 April 2006 hutang DW di BPD Jateng sebesar Rp 473.275.100,- (empat ratus tujuh puluh tiga juta dua ratus tujuh puluh lima ribu seratus rupiah) dilunasi secara tunai oleh WB yang merupakan

\footnotetext{
${ }^{7}$ Chairul Naas, Nilai Keberadaan Saksi dalam Akta PPAT, Pradnya Paramitha, Jakarta, 2014, hal. 65.

${ }^{8}$ H.M. Kamaluddin Lubis, Hukum Pembuktian Pidana dan Perdata Dalam Teori dan Praktek, Medan : 1992, hal. 18.

${ }^{9}$ Ruslan Alamsyah, Kajian Yuridis terhadap PP No. 37 Tahun 1998 tentang Peraturan Jabatan PPAT, Erlangga, Jakarta, 2011, hal. 168
}

\section{DQC Review Vol. 2 No.2 Tahun 2020. E-ISSN: 2623-2928}


kakak kandung dari DW dan ibu dari DS selaku tergugat 2 (dua) serta nenek dari DZAM selaku tergugat 3 (tiga).

Sertipikat hak milik No. 1113 yang sebelumnya diagunkan dengan jaminan hak tanggungan ke BPD Jateng setelah di roya diambil oleh WB. Tahun 2009 DW terkejut karena adanya rehab bangunan yang berdiri di atas tanah miliknya (objek sengketa) tanpa seizin DW. Pendirian bangunan di atas tanah milik DW tersebut dilakukan oleh WB yang menyatakan bahwa tanah seluas $324 \mathrm{~m}^{2}$ dengan sertipikat hak milik No. 1113 atas nama DW telah beralih menjadi atas nama DZAM. WB bersama-sama dengan DS dan DZAM yang seolah sebagai pembeli dengan bantuan PPAT EB melakukan jual beli objek sengketa kepada DZAM ataupun kepada siapapun juga. Akibat hukum jual beli tersebut maka sertipikat hak milik No. 1113 beralih nama dari nama DW kepada nama DZAM dengan menggunakan akta jual beli No. 526/2008 yang dibuat oleh PPAT EB.

\section{Metode Penelitian}

Jenis penelitian ini adalah penelitian yuridis empiris. Penelitian ini bersifat deskriptif analitis, yang mengungkapkan peraturan perundang-undangan yang berkaitan dengan teori-teori hukum yang menjadi objek penelitian. ${ }^{10}$ Deskriptif analitis merupakan metode yang dipakai untuk menggambarkan suatu kondisi atau keadaan yang sedang terjadi atau berlangsung yang bertujuan agar dapat memberikan data seteliti mungkin mengenai objek penelitian sehingga mampu menggali hal.-hal. yang bersifat ideal, kemudian dianalisis berdasarkan teori hukum atau peraturan perundang-undangan yang berlaku. ${ }^{11}$

Teknik pengumpulan data dilakukan dengan cara penelitian kepustakaan (Library Research). Studi ini dilakukan dengan jalan meneliti dokumen yang ada, yaitu dengan bahan hukum dan informasi baik yang berupa buku, karangan ilmiah, peraturan perundang-undangan dan bahan tertulis lainnya yang berkaitan dengan penelitian ini, yaitu dengan mencari, mempelajari dan mencatat serta menginterpretasikan hal.-hal. yang berkaitan dengan objek penelitian yaitu tentang pembuatan akta autentik PPAT dengan menggunakan saksi-saksi sesuai ketentuan hukum yang termuat dalam Pasal 22 PP No. 24 Tahun 2016tentang Peraturan Jabatan PPAT. $^{12}$

${ }^{10}$ Ronny Hanitijo Soemitro, Metodologi Penelitian Hukum dan Jurumateri, Jakarta, Ghal.ia Indonesia, 1994, hal. 105.

${ }^{11}$ Ibid, hal. 223.

${ }^{12}$ Rony Hanitjo Soemitro, Op Cit, 225

\section{ReCltcol Vol. 2 No.2 Tahun 2020. E-ISSN: 2623-2928}


Analisis data merupakan proses pengorganisasian dan mengurutkan data ke dalam kategori-kategori satuan uraian dasar, sehingga ditemukan tema dan dapat dirumuskan hipotesis kerja, seperti yang disaran oleh data. ${ }^{13}$ Analisis data yang akan dilakukan secara kualitatif. Kegiatan ini diharapkan akan dapat memudahkan dalam menganalisis permasalahan yang akan dibahas, menafsirkan dan kemudian menarik kesimpulan. Peraturan perundang-undangan dianalisis secara kualitatif dengan menggunakan logika berfikir dalam menarik kesimpulan yang dilakukan secara deduktif. ${ }^{14}$

\section{Pembahasan}

\section{Pengaturan Hukum Tentang Saksi Dalam Akta PPAT}

Akta PPAT di bidang peralihan hak atas tanah yang telah terdaftar atau yang telah bersertipikat merupakan akta autentik yang disamping memberikan kepastian hukum terhadap para pihak yang melakukan peralihan hak atas tanah, juga dipakai sebagai dasar untuk melakukan balik nama di kantor pertanahan tempat dimana tanah tersebut berada. ${ }^{15}$

Saksi instrumentair dalam kedudukannya sebagai saksi dalam pembuatan akta PPATtidak menjabat suatu jabatan atau pekerjaan sebagai yang dimaksud dalam pasal 322 KUH Pidana tersebut di atas. Oleh karena itu apabila saksi instrumentair membocorkan isi dari suatu akta, maka perbuatan tersebut merupakan suatu perbuatan melawan hukum sebagaimana yang dimaksud dalam Pasal 1365 KUH Perdata. ${ }^{16}$

Dalam pembuatan suatu akta PPAT keberadaan saksi-saksi adalah mutlak. Jika suatu akta PPAT tidak melibatkan saksi-saksi maka akta tersebut adalah bukan akta autentik, melainkan suatu akta yang berkekuatan sebagai akta yang dibuat dibawah tangan dan karena itu akta PPAT tersebut tidak sah secara hukum dalam hal. peralihan hak atas tanah yang telah terdaftaftar atau yang telah bersertipikat. PPAT dalam peresmian akta di bidang pertanahan, harus membacakan akta tersebut di

${ }^{13}$ Lexy j. Moleong, Metodologi penelitian Kualitatif, Bandung; Remaja Rosdakarya. 2004, hal. 280 .

${ }^{14}$ Jhony Ibrahim, Op Cit, hal. 393. Penarikan kesimpulan yang dilakukan secara deduktif, yakni menarik kesimpulan dari suatu permasalahan yang bersifat umum terhadap permasalahan yang konkret.

15 Habib Adjie, Meneropong Khazanah Notaris dan PPAT Indonesia, PT Citra Aditya Bandung, Bandung, 2009, hal. 100.

16 Purbacaraka, Purnadi dan Ridwan Hal.im, Hak Milik Keadilan dan Kemakmuran Tinjauan Falsafah Hukum, Ghal.ia Indonesia, Jakarta.1982,hal. 117.

\section{ReCltcol Vol. 2 No.2 Tahun 2020. E-ISSN: 2623-2928}


depan para penghadap dan para saksi, untuk kemudian ditandatangani oleh para pihak dan para saksi tersebut. ${ }^{17}$

Para saksi instrumentair bukan berarti tidak mengerti sama sekali terhadap isi suatu akta yang dibuat oleh/dihadapan PPAT. Saksi instrumentair PPAT adalah juga merupakan karyawan PPAT yang seharusnyamengetahui formalitas-formalitas yang dilakukan dalam hal. pembuatan akta tersebut. Karyawan PPATsebagai saksi instrumentair berperan sejak pengumpulan data-data pendukung dari akta tersebut, pemba aran segala biaya -biaya yang berhubungan dengan pembuatan akta, bahkan sampai dengan pengetikan dan pen yaksian pembacaan dan penandatanganan akta, para saksi instrumentair ini sangat memahami segala sesuatu yang terdapat dalam akta itu. ${ }^{18}$ Tapi hal. ini tidak menyebabkan para saksi tersebut menjadi bertanggungjawab akan segala sesuatu yang nantinya akan terjadi terhadap akta. Karena saksi instrumentair ini hanya menyaksikan apakah PPAT telah menjalankan syarat-syarat formalitas pembuatan suatu akta pada saat pembuatan akta tersebut, Oleh karena itu dapat dikatakan bahwa dua orang saksi instrumentair dalam pembuatan akta autentik PPAT merupakan alat bukti ysng sah yang menyaksikan langsung pembuatan akta autentik PPAT tersebut, apabila dikemudian hari akta PPAT tersebut mengalami permasalahan hukum. ${ }^{19}$

Tugas dan kewenangan pejabat umum yaitu memberikan pelayanan kepada umum. Konsep umum pada definisi ini bukan pada semua bidang, tetapi hanya pada bidang-bidang tertentu dan khusus, seperti pembuatan akta.7 Oleh karena itu PPAT berwenang membuat akta dari pada perjanjian-perjanjian yang bermaksud memindahkan hak atas tanah, memberikan sesuatu hak baru atas tanah atau meminjam uang dengan hak atas tanah sebagai tanggungan. ${ }^{20}$

Berlakunya UUPA dan atas dasar ketentuan Pasal 19 PP No. 10 Tahun 1961 sebagai pelaksana UUPA, ditentukan bahwa "Setiap perjanjian yang bermaksud mengalihkan hak atas tanah atau meminjam uang dengan hak atas tanah sebagai tanggungan, harus dibuktikan melalui suatu akte yang dibuat oleh dan dihadapan penjabat yang ditunjuk oleh Menteri Agraria”. Akta yang dimaksud harus dibuat oleh dan di hadapan pejabat yang ditunjuk khusus untuk itu, yaitu PPAT. ${ }^{21}$ Pengaturan hukum tentang saksi dalam akta PPAT diatur dalam Pasal 22 PP No. 24 Tahun 2016

\footnotetext{
${ }^{17}$ SoerjonoSoekanto, Pengantar Penelitian Hukum, Universitas Indonesia, Jakarta.1986, hal..35.

${ }^{18}$ Saleh, K. Wantjik, Hak anda Atas Tanah, Ghal.ia Indonesia, Jakarta. 1985,hal. 50.

${ }^{19}$ Suandra I Wayan, Hukum Pertanahan Indonesia, Rineka Cipta, Jakarta.1991, hal. 90.

${ }^{20}$ Boedi Harsono, Beberapa Analisis Tentang Hukum Agraria II, Esa Studi Klub, Jakarta.1978,hal. 75.

${ }^{21}$ Saleh, Wintjik. Hak Anda Atas Tanah. cet XXI. Jakarta: P.T. Intermasa, 1987, hal. 125.

\section{ReCltal}


tentang perubahan atas PP No. 37 Tahun 1998 tentang peraturan jabatan PPAT yang menyebutkan bahwa akta PPAT harus dibacakan/dijelaskan isinya kepada para pihak dengan dihadiri sekurang-kurangnya oleh 2 (dua) orang saksi sebelum ditandatangani seketika itu juga oleh para pihak, saksi-saksi dan PPAT.

Kewajiban menggunakan minimal dua orang saksi sebagaimana asas hukum yang menyebutkan bahwa sunus testis nullus testis (satu saksi bukanlah saksi). Oleh karena itu penggunaan dua orang saksi dalam pembuatan akta autentik PPAT merupakan suatu syarat yang ditentukan oleh hukum pembuktian untuk sahnya suatu akta PPAT. Berdasarkan uraian tersebut Notaris PPAT Kota Medan Helena, SH, MKn juga menyatakan bahwa "ketentuan hukum tentang jumlah saksi dalam pembuatan akta autentik PPAT minimal 2 orang saksi berasal dari pegawai PPAT itu sendiri, karena pada dasarnya sudah ada ketentuan penandatanganan akta PPAT harus dihadiri oleh dua orang saksi dan ini mengacu pada PP No. 37 Tahun 1998 Pasal 22 yang menyebutkan bahwa Akta PPAT harus dibacakan/dijelaskan isinya kepada para pihak dengan dihadiri oleh sekurang-kurangnya 2 orang saksi sebelum ditandatangani seketika oleh para pihak saksi-saksi dan PPAT". ${ }^{22}$

Berdasarkan uraian tersebut di atas maka dapat dikatakan bahwa pengaturan hukum tentang saksi dalam akta PPAT termuat dalam ketentuan Pasal 22 PP No. 24 Tahun 2016 tentang perubahan atas PP No. 37 Tahun 1998, tentang peraturan jabatan PPAT, Pasal 18 ayat 3,4 dan 5 peraturan Menteri Negara Agraria/Kepala Badan Pertanahan Nasional (BPN) Nom4 Tahun 1999 Tentang Ketentuan Pelaksanaan Peraturan Pemerintah Nomor 37 Tahun 1998 tentang Peraturan Jabatan PPAT, dan Pasal 1895-1912 KUH Perdata dalam uraian mengenai kriteria saksi yang diakui dalam pembuatan akta PPAT. ${ }^{23}$

\section{Akibat Hukum Terhadap Akta PPAT Yang Penandatanganannya Dilakukan Tidak Dihadapan Dua Orang Saksi}

Akta PPAT yang merupakan akta autentik karena akta PPAT di bidang pertanahan dan satuan rumah susun tersebut hanya diberikan kewenangannya oleh peraturan perundang-undangan dalam hal. ini PP No.24 Tahun 2016. Konsep akta autentik berasal dari ketentuan Pasal 1868 Burgelijk Wetboek (BW/ Kitab UndangUndang Hukum Perdata) yang menyatakan bahwa "suatu akta autentik adalah suatu akta yang dalam bentuk yang ditentukan oleh undang-undang dibuat oleh atau dihadapan pejabat umum yang berkuasa untuk itu di tempat dimana akta itu dibuat".

\footnotetext{
${ }^{22}$ Wawancara dengan Notaris Kota Medan Helena, SH, MKn Pada Hari Selasa Pukul 14.00 WIB Di Ruang Kerjanya.

${ }^{23}$ Mustofa. Tuntunan Pembuatan Akta-Akta PPAT. Yogyakarta: KaryaMedia. 2010, hal. 120.

\section{ReCl teview Vol. 2 No.2 Tahun 2020. E-ISSN: 2623-2928}


Berdasarkan pada tanggungjawab yang dimiliki oleh PPAT dalam hal. pembuatan akta otentik, PPAT diharuskan harus mengambil sikap teliti atau berhatihati dalam menghadapi setiap kasus, karena seorang PPAT telah mempunyai profesionalitas secara teoritis maupun praktis. Dengan begitu apabila seorang PPAT melakukan kesalahan dalam pembuatan akta, dan mengakibatkan akta tersebut cacat hukum maka dapat dikatakan telah terjadi penyalahgunaan wewenang, karena PPAT bersangkutan menyadari bahwa sebagai pejabat umum yang tugasnya telah diatur oleh undang-undang, maka setiap PPAT dituntut untuk menangani suatu kasus yang berkaitan dengan wewenangnya, dan tidak dapat dilepaskan dari tuduhan adanya penyalahgunaan wewenang.

Suatu akta autentik PPAT dikatakan terdegradasi kekuatan pembuktiannya menjadi akta dibawah tangan apabila ketentuan hukum tentang prosedur dan tata cara pembuatan akta autentik PPAT tersebut tidak dipenuhi atau dilanggar oleh PPAT tersebut.Penandatangan akta PPAT yang dilakukan tidak dihadapan PPAT, merupakan suatu perbuatan melawan hukum yang dilakukan oleh PPAT terhadap ketentuan Pasal 22 PP No. 24 Tahun 2016 tentang Peraturan Jabatan PPAT dan Pasal 18 ayat 3 Peraturan Menteri Negara Agraria No.4 Tahun 1999 tentang peraturan pelaksana PP No 37 Tahun 1998 tentang peraturan jabatan PPAT. Hal.tersebut dipertegas oleh Binsar Simanjuntak, SH Notaris/PPAT Kota Medan yang menyatakan bahwa "Akta autentik yang tidak ditandatangani saksi-saksi secara bersamaan akan mengakibatkan akta tersebut menjadi tidak sah (dibawah tangan) seperti yang telah ditentukan Undang-Undang PP Nomor 24 Tahun 1997 Pasal 101 ayat 2 menyatakan pembuatan Akta PPAT harus disaksikan oleh sekurang-kurangnya dua orang saksi yang menurut ketentuan Peraturan Perundang-Undangan yang berlaku memenuhi syarat untuk bertindak sebagai saksi dalam suatu perbuatan hukum yang memberikan kesaksian antara lain kehadiran para pihak atau kuasanya, keberadaan dokumendokumen yang ditunjuk dalam pembuatan akta dan telah dilaksanakan pembuatan hukum"24, sehingga akibat hukum yang akan ditimbulkan terhadap akta autentik PPAT adalah akta autentik PPAT tersebut akan menjadi cacat hukum dan hanya memiliki kekuatan sebagai akta di bawah tangan. ${ }^{25}$

Analisis Hukum Pertimbangan Majelis Hakim Dalam Putusan Pengadilan Negeri Karanganyar No. 16/Pdt.G/2015/Pn.Krg

\footnotetext{
${ }^{24}$ Wawancara dengan Notaris Kota Medan Binsar Simanjuntak, SH Notaris/PPAT Pada Hari Senin, Tanggal 28 April 2020, Pukul 16.00 di Ruang Kerjanya.

25 Muhammad, Abdul Kadir, Hukum dan Penelitian Hukum, PT. Citra Aditya Bakti , Bandung.2004,hal. 91.
}

\section{ReCltal Voview 2 No.2 Tahun 2020. E-ISSN: 2623-2928}


Berdasarkan Putusan Pengadilan No. 16/Pdt.G/2015/PN.Krg tentang sengketa keabsahan akta PPAT dimana penggugat DW mengajukan gugatan kepada WB sebagai tergugat 1 (satu), DS sebagai tergugat 2 (dua), DZAM sebagai tergugat 3 (tiga), EB (PPAT) sebagai tergugat 4 (empat). Kasus ini diawali dengan adanya hutang dari DW kepada Bank BPD Jateng sebesar Rp 600.000.000,- (enam ratus juta rupiah) dengan jaminan sertipikat hak miliki No. 113 dengan luas tanah $\pm 324 \mathrm{~m}^{2}$ atas nama DW terletak di Badranasri RT.02 RW.11 Kelurahan Cangakan, Kecamatan Karanganyar, Kabupaten Karanganyar, Jawa Tengah. Hutang DW tersebut diangsur rutin setiap bulan oleh DW hingga Maret 2006 dan masih tersisa total hutang DW Rp 473.275.100,- (empat ratus tujuh puluh tiga juta dua ratus tujuh puluh lima ribu seratus rupiah). WB sebagai tergugat 1 (satu) menemui DW selaku penggugat dengan maksud memberi pinjaman kepada DW sebesar sisa hutang DW di BPD Jawa Tengah tersebut. DW menyetujui pemberian pinjaman dari WB sehingga pada Tanggal 3 April 2006 hutang DW di BPD Jateng sebesar Rp 473.275.100,- (empat ratus tujuh puluh tiga juta dua ratus tujuh puluh lima ribu seratus rupiah) dilunasi secara tunai oleh WB yang merupakan kakak kandung dari DW dan ibu dari DS selaku tergugat 2 (dua) serta nenek dari DZAM selaku tergugat 3 (tiga).

Sertipikat hak milik No. 1113 yang sebelumnya diagunkan dengan jaminan hak tanggungan ke BPD Jateng setelah di roya diambil oleh WB. Tahun 2009 DW terkejut karena adanya rehab bangunan yang berdiri di atas tanah miliknya (objek sengketa) tanpa seizin DW. Pendirian bangunan di atas tanah milik DW tersebut dilakukan oleh WB yang menyatakan bahwa tanah seluas $324 \mathrm{~m}^{2}$ dengan sertipikat hak milik No. 1113 atas nama DW telah beralih menjadi atas nama DZAM. WB bersama-sama dengan DS dan DZAM yang seolah sebagai pembeli bersama dengan PPAT EB melakukan jual beli objek sengketa kepada DZAM ataupun kepada siapapun juga. Akibat hukum jual beli tersebut maka sertipikat hak milik No. 1113 beralih nama dari nama DW kepada nama DZAM dengan menggunakan akta jual beli No. 526/2008 yang dibuat oleh PPAT EB. ${ }^{26}$

Berdasarkan perbuatan hukum yang dilakukan oleh WB, ES, DZAM dan EB secara bersama-sama mengakibatkan kerugian atas hak dan kepentingan DW karena telah kehilangan harta benda berupa hak milik atas tanah dengan SHM No. 1113 yang telah beralih nama dari nama DW menjadi nama DZAM tanpa sepengetahuan pemilik tanah yang sah yaitu DW. Berdasarkan hal. tersebut maka DW mengajukan gugatan ke Pengadilan Negeri Karanganyar dan berdasarkan putusan No.

26 Rahmat Hidayat, Pengalihan Hak Atas Tanah dan Peranan PPAT,Sumber Media, Jakarta.2003,hal. 85.

\section{ReClţ Review Vol. 2 No.2 Tahun 2020. E-ISSN: 2623-2928}


16/Pdt.G/2015/PN.Krg dalam amar putusannya menyebutkan mengabulkan gugatan penggugat DW untuk sebagian, menyatakan tergugat empat PPAT EB telah melakukan perbuatan melawan hukum karena menjalankan jabatan sebagai Notaris/PPAT secara tidak sah dan bertentangan dengan kewajibannya sebagaimana telah ditetapkan dalam PP No. 37 Tahun 1998 tentang Peraturan Jabatan Notaris. Menolak gugatan penggugat DW untuk selain dan selebihnya. ${ }^{27}$

Majelis Hakim Pengadilan Negeri Karang Anyar dalam pertimbangan hukum nya berpendapat bahwa perjanjian jual beli sebidang tanah dan bangunan dengan Sertipikat Hak Milik (SHM) Nomor1113 antara pihak Pemilik tanah DW selaku penggugat dengan pihak pembeli DZAM selaku pihak tergugat III yang diwakili oleh anaknya WB dan DS selaku Tergugat II adalah sah menurut hukum;

Mengenai Akta Jual Beli Nomor. 526/2008 yang diterbitkan oleh Notaris/PPAT EB selaku Tergugat IV menurut pertimbangan hukum majelis hakim pengadilan negeri Karang Anyar telah dibuat dengan cara melawan hukum.Penggugat tidak menyangkal telah bertandatangan di dalam Akta Jual Beli tersebut, tidak juga menyatakan bahwa tanda tangan di atas nama dirinya yang ada dalam Akta Jual Beli tersebut adalah palsu, hal. tersebut diperkuat dengan keterangan dari Saksi Farid Danny Setyawan Penyidik pada Polres Karanganyar, yang pernah menyarankan untuk membuat laporan telah terjadi pemalsuan surat, akan tetapi Penggugat tidak mau. Hal. tersebut telah menjadi petunjuk yang meyakinkan bagi Majelis Hakim, bahwa Penggugat memang benar telah bertanda tangan pada Akta Jual Beli Nomor 526/2008 tersebut. $^{28}$

Majelis hakim dalam pertimbangan hukumnya berpendapat bahwa penandatanganan yang dilakukan oleh pihak pemilik tanah/penjual di atas kertas akta jual-beli hak atas tanah PPAT yang masih kosong dan tidak disaksikan oleh dua orang saksi tersebut adalah tidak sah secara hukum, karena saksi dikedudukan hukum yang secara sah bertugas untuk menyaksikan dan mengetahui apa yang dia saksikan dalam pembuatan suatu akta jual beli serta dapat mempertanggungjawabkan apa yang dia saksikan dan dilihat pada saat penandatanganan akta dilangsungkan. ${ }^{29}$ dan akta tersebut tidak memiliki kekuatan hukum mengikat dalam pelaksanaan peralihan hak atas tanah melalui jual beli dengan menggunakan akta PPAT tersebut. Selain itu DW selaku pihak pemilik tanah/penjual dan sebagaipenggugat tidak mengetahui dan

${ }^{27}$ Aldi Subhan Lubis. Tanggung Jawab Pejabat Akta Tanah Yang Melakukan Perbuatan Melawan Hukum Dalam Pembuatan Akta. Jurnal. 2009.

${ }^{28}$ Muhammad, Abdul Kadir. Hukum Perikatan, Bandung: Citra Aditya Bakti. 2014,hal. 53.

${ }^{29}$ Wawancara dengan Notaris/PPAT Holdin Simbolon, SH., MknNotaris/PPAT pada hari Rabu, 29 April 2020, Pukul 15.00 WIB di Ruang Kerjanya.

\section{ReCIt}


memahami tujuan yang sebenarnya mengapa penggugat menandatangani akta jual beli hak atas tanah No.526/2008 yang masih kosong tersebut. ${ }^{30}$

Akta jual beli Nomor.526/2008 tersebut cacat secara formil dalam pembuatannya, sehingga sifat keontentikan dari akta tersebut hilang dan terdegradasi menjadi akta dibawah tangan, karena tidak lagi mempunyai kekuatan pembuktian yang sempurna. Menimbang, bahwa berdasarkan pertimbangan tersebut Hakim Anggota I berpendapat bahwa Tergugat IV dalam mengesahkan dan membuat Akta Jual Beli akta jual beli Nomor. 526/2008 tersebut telah melakukan perbuatan melawan hukum, pertimbangan hukum majelis hakim menyatakan bahwa apabila suatu akta autentikterdegradasi menjadi akta dibawah tangan, maka tidak serta merta/otomatis meniadakan isi dari perjanjian tersebut, Undang-Undang tidak mengatur sah tidaknya isi perjanjian,sehingga penilaian mengenai keabsahan isi dari perjanjian tersebut berada di tangan hakim.

Perbuatan hukum peralihan hak atas tanah, bangunan dan satuan rumah susun yang telah terdaftar/bersertipikat pada prinsipnya tidak dapat dilakukan dengan menggunakan akta di bawah tangan atau akta PPAT yang sudah terdegradasi menjadi akta di bawah tangan. Oleh karena itu akta PPAT yang dibuat dengan tujuan untuk melakukan perbuatan hukum pengalihan hak atas tanah yang telah mengandung unsur cacat formal adalah tidak sah dan tidak memiliki kekuatan hukum untuk digunakan sebagai dasar peralihan hak atas tanah, bangunan dan satuan rumah susun yang sudah terdaftar atau telah bersertipikat tersebut. ${ }^{31}$

Putusan Pengadilan Negeri Karang Anyar No.16./Pdt.G/2015/PN Krg yang dalam amar putusannya menyatakan bahwa akta jual beli no.526/2008 yang dibuat oleh Notaris/PPAT EB tersebut mengandung unsur cacat formal dan Notaris/PPAT tersebut telah melakukan perbuatan melawan hukum dalam pembuatan akta jual beli hak atas tanah adalah sudah tepat dan sesuai dengan ketentuan hukum yang berlaku. Namun demikian amar outusan pengadilan negeri karang anyar No.16/Pdt.G/2015/PN Krg tersebut yang menyatakan bahwa Akta Jual beli No.526/2008 yang telah mengandung cacat formal tetap dinyatakan sah sebagai dasar hukum peralihan hak atas tanah, bangunan dan satuan rumah susun yang telah terdaftar/telah bersertipikat tersebut adalah kurang tepat. Apabila dasar peralihan hak atas tanah tersebut dilakukan berdasarkan akta PPAT yang telah cacat hukum dan aktanya telah terdegradasi menjadi akta di bawah tangan, maka pada prinsipnya peralihan hak atas tanah,bangunan dan satuan rumah susun yang telah terdaftar/telah

30 Perangin-Angin, Effendi. Praktek Jual Beli Tanah, Jakarta: Rajawali Pers,1997, hal. 20.

31 Sutedi, Ardian. Peralihan Hak Atas Tanah dan Pendaftarannya, Jakarta: Sinar Grafika.2007,hal. 58.

\section{ReCl teview Vol. 2 No.2 Tahun 2020. E-ISSN: 2623-2928}


bersertipikat tersebut adalah cacat hukum juga. ${ }^{32}$ Karena itu dapat dikatakan bahwa peralihan hak atas tanah dengan dasar hukum akta jual beli yang dibuat oleh Notaris/PPAT EB yang telah mengandung unsur cacat hukum sehingga terdegradasi menjadi akta di bawah tangan adalah tidak berkekuatan hukum juga, karena peraturan perundang-undangan sebagaimana termuat dalam pasal 37 PP No 24 Tahun 1997 tentang pendaftaran tanah menyebutkan bahwa setiap peralihan hak atas tanah, bangunan dan satuan rumah susun yang telah terdaftar/bersertipikat wajib dilakukan dengan menggunakan akta autentik PPAT. ${ }^{33}$

WB sebagai pemilik tanah/penggugat dapat mengajukan gugatan pembaralan sertipikat hak milik No.113 ke PTUN dimana hak kepemilikan atas tanah tersebut telah beralih dari nama DW selaku pemilik tanah asal menjadi nama WB sebagai pihak pembeli dengan dasar hukum akta jual beli No.526/2008 ysng dibuat oleh Notaris/PPAT EB dengan cara melawan hukum sehingga mengandung unsur cacat hukum, Oleh karena itu akta jual beli No.526/2008 yang dibuat oleh Notaris/PPAT EB tersebut pada prinsipnys tidak dapat dijadikan dasar hukum dalam peralihan nama pemegang hak milik atas tanah dari nama DW menjadi Nama WB. ${ }^{34}$

\section{Penutup}

\section{Kesimpulan}

1. Pengaturan hukum tentang saksi dalam akta PPAT termuat di dalam Pasal 21 dan 22, PP No. 24 Tahun 2016 tentang perubahan atas PP No. 37 Tahun 1998 tentang peraturan jabatan PPAT, Pasal 18 ayat 3,4 dan 5 peraturan Menteri Negara Agraria/Kepala Badan Pertanahan Nasional (BPN) Nomor 1 Tahun 2006 Tentang Ketentuan Pelaksanaan Peraturan Pemerintah Nomor 37 Tahun 1998 tentang Peraturan Jabatan PPAT, Pasal 1895-1912 KUH Perdata dalam uraian mengenai kriteria saksi yang diakui dalam pembuatan akta PPAT dan Pasal 37 PP No. 24 Tahun 1997 tentang pendaftaran tanah.

2. Akibat hukum terhadap akta PPAT yang penandatanganannya dilakukan tidak dihadapan dua orang saksi adalah bahwa akta PPAT tersebut terdegradasi menjadi akta dibawah tangan, karena mengandung cacat hukum secara formal yaitu tidak sesuai dengan prosedur dan tata cara pembuatan akta autentik

\footnotetext{
${ }^{32}$ Nelly Sriwahyuni Siregar. Tinjauan Kedudukan Kuasa Mutlak Dalam Peralihan Hak Atas Tanah oleh Notaris / PPAT. Jurnal. 2008.

33 Dona Christin. Analisis Atas Diketahuinya Cacat Yuridis Pada Akta Jual Beli Tanah Dan Rumah Yang Dibuat Oleh Ppat (Putusan Mahkamah Agung No. 2333 K/PDT/2015). Jurnal. 2013.

${ }^{34}$ Muhammad Arfan. Analisis Yuridis Peralihan Hak Tanah Milik Adat Dengan Akta Jual Beli Yang Dibuat Oleh PPAT (Studi Kabupaten Aceh Besar). Jurnal. 2014.
}

\section{ReCltal Veview Vol. 2 No.2 Tahun 2020. E-ISSN: 2623-2928}


PPAT sebagaimana telah ditetapkan di dalam Pasal 21 dan 22 PP No. 37 Tahun 1998 tentang Peraturan Jabatan PPAT.

3. Analisis hukum pertimbangan Majelis Hakim dalam Putusan Pengadilan Negeri Karanganyar No. 16/Pdt.G/2015/PN.Krg yang menyatakan bahwa PPAT telah melakukan perbuatan melawan hukum dan akta autentik tersebut telah terdegradasi menjadi akta di bawah tangan adalah telah tepat dan sesuai dengan peraturan perundnag-undangan yang berlaku. Namun Putusan Pengadilan negeri Karanganyar yang menyebutkan bahwa Akta PPAT mengenai jual beli sebagaimana termuat di dalam akta jual beli Nomor 526/2008, yang sudah terdegradasi menjadi akta dibawah tangan tersebut tetap memiliki kekuatan hukum sebagai dasar pengalihan hak atas tanah sebagaimana termuat dalam sertipikat Hak Milik Nomor 1113 yang telah dilakukan proses hukum balik nama dari nama DW menjadi nama WB adalah kurang tepat karena perbuatan hukum balik nama tersebut dilaksanakan berdasarkan akta jual beli No. 526/2008 yang mengandung unsur cacat hukum formal dalam pelaksanaan pembuatannya sehingga proses hukum balik nama tersebut juga mengandung unsur cacat hukum, sehingga dapat dilakukan upaya hukum gugatan pembatalan SHM No. 1113 tersebut oleh pemilik tanah yang lama ke peradilan tata usaha negara (PTUN) untuk membatalkan peralihan hak milik atas tanah pada SHM No. 1113 tersebut.

\section{Saran}

1. Hendaknya PPAT yang melanggar ketentuan hukum dalam pembuatan akta autentik dijatuhi sanksi administratif, perdata maupun pidana berdasarkan Ketentuan Pasal 13 dan 38 Peraturan Menteri Agraria/Tata Ruang Kepala Badan Pertanahan Nasional No. 2 Tahun 2018 tentang pembinaan dan pengawasan Pejabat Pembuat Akta Tanah (PPAT), Pasal 10 PP No. 24 Tahun 2016 tentang perubahan atas PP No. 37 Tahun 1998 tentang Peraturan Jabatan PPAT.

2. Hendaknya PPAT tidak melakukan perbuatan melawan hukum dalam pembuatan akta autentik PPAT khususnya dalam hal. akta jual beli hak atas tanah agar terhindar dari permasalahan hukum khususnya tentang gugatan ganti rugi terhadap PPAT tersebut maupun gugatan pembatalan akta PPAT yang mengandung unsur perbuatan melawan hukum dalam pembuatannya ke Pengadilan Tata Usaha Negara.

3. Akta PPAT yang mengandung unsur cacat hukum formal dalam pembuatannya khususnya dalam hal. akta jual beli, hak atas tanah, tidak dapat dijadikan dasar dalam pelaksanaan peralihan hak milik atas tanah dan proses

\section{ReCltol Review Vol. 2 No.2 Tahun 2020. E-ISSN: 2623-2928}


balik nama di Kantor Pertanahan tempat dimana tanah tersebut berada, karena apabila dasar peralihan hak atas tanah tersebut mengandung unsur cacat hukum maka seluruh produk hukum yang dihasilkan dari dasar produk hukum yang mengandung unsur cacat hukum tersebut akan menjadi cacat hukum pula, sehingga tidak memiliki kekuatan hukum dan dapat digugat pembatalannya ke PTUN.

\section{Daftar Pustaka}

\section{Buku:}

Adjie, Habib, Kewenangan PPAT sebagai Pejabat Umum Berdasarkan PP No. 37 Tahun 1998 tentang Peraturan Jabatan PPAT, Bandung, RefikaAditama, 2008.

Kebatalan dan Pembatalan Akta PPAT, Refika Aditama, Bandung, 2014.

Saksi Perdata dan Administratif terhadap PPAT sebagai Pejabat Publik, Refika Aditama, Bandung, 2014.

Alamsyah, Ruslan, Kajian Yuridis terhadap PP No. 37 Tahun 1998 tentang Peraturan Jabatan PPAT, Erlangga, Jakarta, 2011.

Andasamista, Komar, PPAT Selayang Pandang, Bandung: Alumni, 1983.

Arief Sidharta, Bernard, Refleksi tentang Struktur Ilmu Hukum, Bandung, Mandar Madju, Cetakan Ke Tiga, 2009.

Asshidiqqie, Jimly dan Safa'at, M. Ali, Teori Hans Kelsen Tentang Hukum, Konstitusi Press, Jakarta, 2006.

Budiono, Herlin. Kumpulan Tulisan Hukum Perdata di Bidang Kenotariatan, Citra Aditya Bakti, Bandung, 2007.

Badrulzaman, Mariam Darus, Kompilasi Hukum Perikatan,Bandung: PT. Citra Aditya Bakti, 2006.

Devi, Irma, Kedudukan Saksi di dalam Akta Autentik PPAT, Rineka Cipta, Jakarta, 2014.

Dwi Saputro, Anke, Jati Diri PPAT Indonesia, Dulu, Sekarang, dan Di Masa Datang, Jakarta : PT.Gramedia Pustaka Utama, 2008.

Fuady, Munir, Pertanggungjawaban Hukum Dalam Teori dan Praktek, Armiko, Bandung, 2007.

Gusmawan, Donni, Perlindungan Hukum di Negara Pancasila, Liberty, Yogyakarta, 2007.

\section{Recitgu|}


Hanitijo Soemitro, Ronny, Metodologi Penelitian Hukum dan Jurumateri, Jakarta, Ghal.ia Indonesia, 1994.

Harahap, M. Yahya, Hukum Acara Perdata tentang Gugatan, Persidangan, Penyitaan, Pembuktian dan Putusan Pengadilan, Sinar Grafika, Jakarta, 2015.

HS, Salim. Keabsahan Saksi dalam Pelaksanaan Pembuatan Akta Autentik PPAT, Tarsito, Bandung, 2015.

Ibrahim, Johny, Teori dan Metodologi Penelitian Hukum Normatif, Surabaya, Bayumedia, 2008.

Kie Tan Thong. studi Notariat, Serba-serbi Praktek Notaris, Ichtiar Baru. Van Hoeve, Jakarta. 2007.

Koenjaraningrat, Metode-Metode Penelitian Masyarakat, Jakarta, Gramedia, 1990.

Kohar, A. PPAT dan Persoalan Hukum, Surabaya : PT. Bina Indra Karya, 1985.

Lubis, Kamaluddin, H.M. Hukum Pembuktian Pidana dan Perdata Dalam Teori dan Praktek, Medan. 1992.

Lubis, M. Solly, Filsafat Ilmu dan Penelitian, Mandar Maju, Bandung, 1994.

M. Hadjon, Philipus, Perlindungan Hukum Bagi Rakyat Indonesia, Bina Ilmu, Surabaya, 2006.

Mertokusumo, Sudikno. Hukum Acara Perdata Indonesia. Liberty. Yogyakarta, 2006.

Mahmud Marzuki, Peter, Penelitian Hukum, Jakarta, Kencana Persada Group, 2010.

Moleong, Lexy J. Metodologi penelitian Kualitatif, Bandung; Remaja Rosdakarya. 2004.

Naas, Chairul, Nilai Keberadaan Saksi dalam Akta PPAT, Pradnya Paramitha, Jakarta, 2014.

Notodisorjo, Soegondo, Hukum Notariat di Indonesia (Suatu Penjelasan). Raja Grafindo Persada, 2013.

Prayuda, Donni, Teori Pertanggungjawaban, Prenada Media, Jakarta, 2009.

Purba, Hasim, Sengketa Pertanahan dan Alternatif Pemecahan, Study Kasus Di Sumatera Utara, CV. Cahaya Ilmu, Medan 2006.

Putri, Irrenera, Tinjauan Yuridis terhadap Perlindungan Karyawan PPAT sebagai Saksi dalam Pembuatan Akta, Erlangga, Surabaya, 2013.

Raharjo, Satjipto, Ilmu Hukum, Bandung, PT. Citra Aditya Bakti, 1991.

Rahim, Abdul dan Lubis, Yamin Muhammad, Hukum Pendaftaran Tanah Edisi Revisi, Mandar Maju, Bandung, 2010.

Rasmanto, Gunawan, Teori Pertanggungjawaban Hukum Menurut Hans Kelsen, Prenada Media, Jakarta, 2014.

\section{ReClţ Review Vol. 2 No.2 Tahun 2020. E-ISSN: 2623-2928}


Saputro, Jati Diri Notaris di Indonesia, Dulu, Sekarang, dan Dimasa Mendatang. Gramedia Pustaka, Jakarta. 2009.

Setia Tunggal, Hadi, Kajian terhadap Peraturan Pemerintah No. 37 Tahun 1998 tentang Peraturan Jabatan PPAT, Jakarta : Harvarindo, 2006.

Sitepu, Runtung, Penelitian Evaluasi Produk-Produk Akta PPAT yang Menimbulkan Masalah Pertanahan, Di Medan, Program Magister Kenotariatan Program Pascasarjana Universitas Sumatera Utara, 2010.

Sjaifurrachman, Habib Adjie, Aspek Pertanggungjawaban PPAT dalam pembuatan Akta, Bandung : Mandar Maju, 2011.

Soekanto, Soerjono dan Mahmudji, Sri, Penelitian Hukum Normatif Suatu Tinjauan Singkat, Jakarta. PT. Raja Grafindo Persada, 1996.

Soekanto, Soerjono, Pengantar Penelitian Hukum, Jakarta, UI Press, 1986. , Pengantar Penelitian Hukum, Jakarta, UIPress, 1986.

Soka, Hasim, Perlindungan Hukum terhadap Saksi dalam Akta PPAT, Refika Aditama, Jakarta, 2015.

Solly Lubis, M. Filsafat Ilmu dan Penelitian, Bandung, Bandar Maju, 1994.

Subekti R. dan Tjitrosudibio, R, Kitab Undang-Undang Hukum Perdata, Jakarta, Pradnya Paramita, 2008.

\section{Jurnal}

Arfan, Muhammad. Analisis Yuridis Peralihan Hak Tanah Milik Adat Dengan Akta Jual Beli Yang Dibuat Oleh PPAT (Studi Kabupaten Aceh Besar). Jurnal. 2014.

Christin, Dona. Analisis Atas Diketahuinya Cacat Yuridis Pada Akta Jual Beli Tanah Dan Rumah Yang Dibuat Oleh Ppat (Putusan Mahkamah Agung No. 2333 K/PDT/2015). Jurnal. 2013.

Handryani, Fine. Akibat Hukum dari Pembuatan Akta Jual Beli Tanah Bersertifikat Yang Tidak Sesuai Dengan Tata Cara Pembuatan Akta PPAT (Studi Pada PPAT di Kabupaten Langkat). Jurnal MKn. 2011.

Harahap, Khairunisyah, Problematika Hukum Sebagai Camat Pejabat Pembuat Akta Tanah Sementara (PPAT/S) Dalam Melaksanakan Peralihan Hak Atas Tanah Tanpa Sertifikat. Jurnal MKn. 2014.

Kosim, Irham, Implementasi Fungsi Pembinaan dan Pengawasan Kepada Pejabat Pembuat Akta Tanah (Studi Kabupaten Deli Serdang). Jurnal MKn. 2017.

Lubis, Subhan Aldi. Tanggung Jawab Pejabat Akta Tanah Yang Melakukan Perbuatan Melawan Hukum Dalam Pembuatan Akta. Jurnal MKn. 2009.

\section{ReCl}


Ramadhan, Hafni Yulida. Perjanjian Peralihan Hak Atas Tanah Yang Dapat Menimbulkan Konflik. Jurnal MKn. 2006.

Siregar, Sriwahyuni Nelly. Tinjauan Kedudukan Kuasa Mutlak Dalam Peralihan Hak Atas Tanah oleh Notaris / PPAT. Jurnal MKn. 2008.

Situmorang, Pantas, Problematika Keotentikan AKTA PPAT. Jurnal MKn. 20008.

Zebua, Sherli Rahmadani. Tinjauan Yuridis Penggunaan Formulir Akta Jual Beli Kapling Perumahan Oleh PPAT di Kota Medan. Jurnal MKn. 2012.

\section{Peraturan Perundang-Undangan}

Peraturan Perundang-Undangan No. 37 Tahun 1998 tentang Peraturan Jabatan PPAT

Peraturan Menteri Agraria dan Kepala Badan Pertanahan Nasional No. 3 Tahun 1997. 